http://dx.doi.org/10.11646/zoosymposia.13.1.15

http://zoobank.org/urn:lsid:zoobank.org:pub:0224775D-0491-4D1C-8B81-93A634FF11A2

\title{
A taxonomic review of pterotracheoid gastropod mollusks from California Current waters off the west coast of North America
}

\author{
ROGER R. SEAPY
}

Department of Biological Science, California State University, 800 No. State College Blvd., Fullerton, CA 92831, USA. E-mail: raseapy@verizon.net

\begin{abstract}
Taxonomic characterization of pterotracheoid gastropods, morphological characteristics and occurrence in California Current waters are reviewed. Single species of atlantid (Atlanta californiensis) and carinariid (Carinaria japonica) from these waters are described and illustrated.
\end{abstract}

\section{Introduction}

Species of pterotracheoids recorded off the the west coast of North America include the atlantid, Atlanta californiensis, and the carinariid, Carinaria japonica; both live at epipelagic depths (surface to $\sim 200 \mathrm{~m}$ ).

SBMNH Santa Barbara Museum of Natural History, Santa Barbara, California, USA.

SD subsequent designation.

\section{Systematics}

\section{Pterotracheoidea Rafinesque, 1814}

Description. Shell thin and transparent, foot enlarged and laterally compressed forming a swimming fin, paired eyes large and image-forming with a spherical lens and basal strip-like retina, radula elongate with sickle-shaped lateral and marginal teeth.

Distribution. Cosmopolitan at tropical to subtropical latitudes, although some are restricted to one or two oceans and two (Atlanta californiensis and Carinaria japonica) are only found in the North Pacific.

Remarks. Pterotracheoidea is the correct name for the Heteropoda, commonly referred to as heteropods.

\section{Atlantidae Rang, 1829}

Atlantidae Wiegmann \& Ruthe, 1832: 518, ex Rang, 1829: 123 (vernacular).

Diagnosis. Shell calcareous, except in Oxygyrus (cartilaginous), laterally compressed, coiled, resulting in flattened, discoid shape with diameter to $10 \mathrm{~mm}$; keel extends outward from last whorl to varying degrees; keel calcareous (Atlanta) or cartilaginous (Protatlanta, Oxygyrus). Operculum chitinous, attached to posterior margin of foot.

Distribution. Most species live in the upper layer of the ocean (the epipelagic zone), which off the west coast of North America extends to a depth of 150 to $200 \mathrm{~m}$. 
Atlanta Lesueur, 1817: 390, pl. 2, figs 1-2. Type species (SD Gray 1847: 149, no. 175): Atlanta peronii .

Diagnosis. Shell and keel calcareous (aragonitic); following metamorphosis larva shell retained as the protoconch of the adult shell spire, with a flat to conical shape and protruding to varied degrees; number of spire whorls ranges from $21 / 2$ to 6 whorls, with smooth to complex surface sculpture.

Remarks. Among the nineteen extant species of Atlanta, only one occurs in temperate waters while the remainder are tropical to subtropical.

The biology and paleontology of atlantids were reviewed by Wall-Palmer et al. (2016). Subsequently, the biogeography and genetic diversity of atlantids were studied by Wall-Palmer et al. (2018).

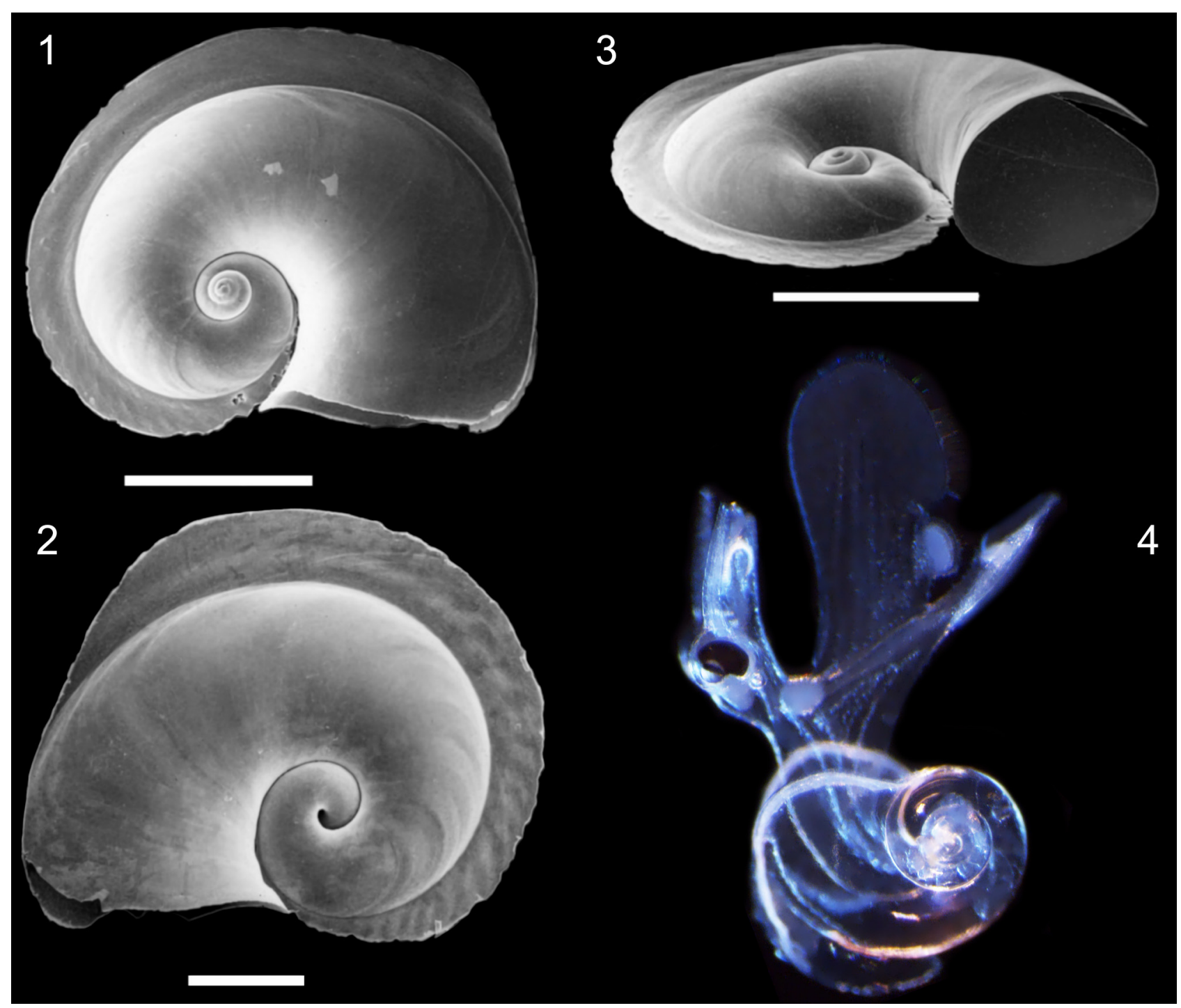

FIGURES 1-4. Atlantidae. Atlanta californiensis from the right side; scale bar $=0.5 \mathrm{~mm}$. 2. Atlanta californiensis shell from left side; scale bar $=1 \mathrm{~mm}$. 3. Atlanta californiensis shell from right side, apertural view; scale bar $=0.5 \mathrm{~mm} .4$. Atlanta californiensis shell from right side; scale bar $=0.5 \mathrm{~mm}$.

\section{Atlanta californiensis Seapy \& Richter, 1993}

(Figures 1-4)

Atlanta californiensis Seapy \& Richter, 1993: 389, figs 1-4, 6a, 6c, 7, 8, 9a, 10a. Holotype SBMNH 140126; San Pedro Basin, California. 
Diagnosis. Shell moderately small (to $3.5 \mathrm{~mm}$ ), laterally compressed, transparent. Spire of $31 / 4$ whorls, shape low conical, coloration variable and attributable to underlying tissues, either clear to uniform light yellow, brown or violet, or mottled light to dark yellow-brown. Suture coloration from clear to light violet or purple. Internal walls partially decalcified and replaced with thin chitinous membranes. Umbilicus deep, wide. Operculum thin, transparent, oval in shape; gyre region lacks raised spines.

Distribution. Limited to the Transition Zone Faunal Province, which includes the California Current (Seapy \& Richter 1993).

Remarks. Abundances in nearshore waters off southern California are low between fall and spring, increasing in summer and peaking in August (Cummings \& Seapy 2003).

\section{Carinariidae Blainville, 1818}

Carinariidae Blainville, 1818: 214.

Diagnosis. Body greatly enlarged, elongate (to $680 \mathrm{~mm}$ in Carinaria cristata), cylindrical, gelatinous, divided into three regions (proboscis, trunk, tail). Sucker small, located on posterior margin of foot.

\section{Carinaria Lamarck, 1801}

Carinaria Lamarck, 1801: 98-99. Type species by monotypy Argonauta vitreus Gmelin, 1791 (= Carinaria cristata (Linnaeus, 1767).

\section{Diagnosis}

Shell and keel calcareous; shell cap-shaped, laterally compressed, covering stalked visceral nucleus. Visceral nucleus, swimming fin opposite each other on posterior portion of trunk. Tail shape, size variable, height of tail crest variable. Swimming fin with small sucker on postero-ventral margin.

\section{Carinaria japonica Okutani, 1955}

(Figures 5-6)

Carinaria japonica Okutani, 1955: 251, figs 1-3. Holotype Tokai Regional Fisheries Research Laboratory, Tokyo (no number assigned). Type locality: $36^{\circ} 21^{\prime} \mathrm{N} 141^{\circ} 00^{\prime} \mathrm{W}$.

Description. Body to $130-150 \mathrm{~mm}$. Shell laterally compressed, triangular in shape; height to basal length ratio $0.8-1.0$; keel width low at shell apex, increasing in height with proximity to shell aperture. Tail moderately large, with tall dorsal crest.
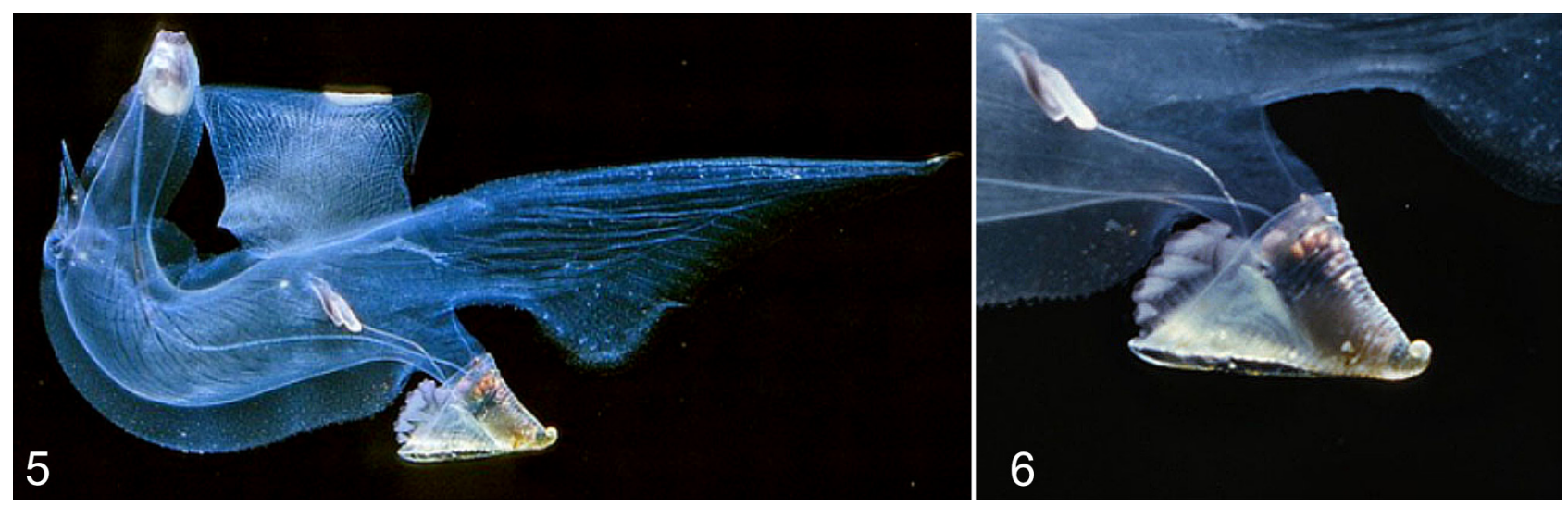

FIGURES 5-6. Carinariidae. 5. Carinaria japonica from right side. 6. Carinaria japonica stalked visceral mass and shell. Note the small protoconch retained at the shell apex. Photographs by David Wrobel, with permission. 
Distribution. Limited to the North Pacific Transition Zone Faunal Province (Seapy 1974), which extends eastward from Japanese waters in a narrow band and then diverges upon approaching the west coast of north America to the north, forming the Alaskan Gyre, and to the south, forming the California Current.

Remarks. Abundance in California Current waters varies seasonally, becoming maximal off southern California in mid-summer (Dales 1953, McGowan 1967, Seapy 1974). From the CalCOFI samples in the North Pacific Dales (1953) had identified C. japonica as C. lamarcki.

\section{References}

Blainville H.M.D. de (1818) Conchyliologie, pp. 168-225, in: Cuvier, F. (ed.) Dictionnaire des Sciences Naturelles, vol. 10. Levrault, Strasbourg \& Le Normant, Paris. 596 pp.

Cummings, F.A. \& Seapy, R.R. (2003) Seasonal abundances of euthecosomatous pteropods and heteropods from waters overlying San Pedro Basin, California. The Veliger, 46, 305-313.

Dales, R.P. (1953) The distribution of some heteropod molluscs off the Pacific coast of North America. Proceedings of the Zoological Society of London, 122, 1007-1015. https://doi.org/10.1111/j.1096-3642.1953.tb00359.x

Gray, J.E. (1847) A list of the genera of recent Mollusca, their synonyms and types. Proceedings of the Zoological Society of London, for 1847, 15, 129-206.

Lamarck, J.B. (1801) Système des animaux sans vertèbres, ou tableau général des classes, des ordres et des genres de ces animaux; Présentant leurs caractères essentiels et leur distribution, d'apres la considération de leurs rapports naturels et de leur organisation, et suivant l'arrangement établi dans les galeries du Muséum d'Histoire Naturelle, parmi leurs dépouilles conservées; Précédé du discours d'ouverture du Cours de Zoologie, donné dans le Muséum National d'Histoire Naturelle l'an 8 de la République. Published by the author and Deterville, Paris: viii +432 pp.

Lesueur, C.A. (1817) Mémoire sur deux nouveaux genres de mollusques, Atlante et Atlas. Journal de Physique, de Chimie, et d'Histoire Naturelle, 85, 390-393.

Linnaeus, C. (1767) Systema naturae, editio duodecima reformata 1(2). L. Salvii, Holmiae, 533-1327 + register.

McGowan, J.A. (1967) Distributional Atlas of pelagic molluscs in the California Current region. California Cooperative Fisheries Investigations, Atlas 6, $218 \mathrm{pp}$.

Okutani, T. (1955) On a new species of Carinaria, C. japonica. Venus, 18, 251-258.

Rang, S. (1829) Manuel de l'histoire naturelle des mollusques et de leurs coquilles, ayant pour base de classification celle de M. le Baron Cuvier. Roret, Paris. 390 pp.

Seapy, R.R. (1974) Distribution and abundance of the epipelagic mollusk Carinaria japonica in waters off southern California. Marine Biology, 24, 243-250. https://doi.org/10.1007/BF00391899

Seapy, R.R. \& Richter, G. (1993) Atlanta californiensis, a new species of atlantid from the California Current. The Veliger, 36, 389-398.

Wall-Palmer, D., Smart, C.W., Kirby, R., Hart, M.B., Peijnenburg, K.T.C.A., \& Janssen, A.W. (2016) A review of the ecology, palaeotology and distribution of atlantid heteropods (Caenogastropoda: Pterotracheoidea: Atlantidae). Journal of Molluscan Studies, 82, 221-234. https://doi.org/10.1093/mollus/eyv063

Wall-Palmer, D., Burridge, A.K., Goetze, E., Stokvis, F.R., Janssen, A.W., Mekkes, L., Moreno-Alcantara, M., Bednarsek, N., Schiotte, T., Sorensen, M.V., Smart, C.W., \& Peijnenburg, K.T.C.A. (2018) Biogeography and genetic diversity of the atlantid heteropods. Progress in Oceanography, 160, 1-25. https://doi.org/10.1016/j.pocean.2017.11.004

Wiegmann, A.F. \& Ruthe, J.F. (1832) Handbuch der Zoologie, Lèudertz, Berlin. 621 pp. https://doi.org/10.5962/bhl.title. 115720 